Original Article

\title{
Antibacterial and bacteriostatic potential of coelomic fluid and body paste of Pheretima posthuma (Vaillant, 1868) (Clitellata, Megascolecidae) against ampicillin resistant clinical bacterial isolates
}

\author{
Potencial antibacteriano e bacteriostático do fluido celômico e pasta corporal de \\ Pheretima posthuma (Vaillant, 1868) (Clitellata, Megascolecidae) contra isolados \\ bacterianos clínicos resistentes à ampicilina
}

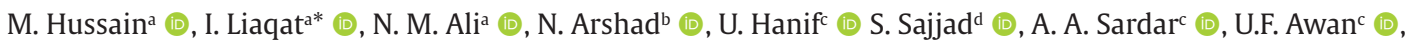 \\ F.S. Khan ${ }^{\mathrm{e}}$ (1) and Slahuddin ${ }^{\mathrm{f}}$ (1) \\ ${ }^{a} G C$ University, Department of Zoology, Microbiology Lab, Lahore, Pakistan \\ bUniversity of Lahore, Institute of Molecular Biology and Biotechnology, Department of Zoology, Lahore, Pakistan \\ 'GC University, Department of Botany, Lahore, Pakistan \\ ¿Lahore College for Women University, Department of Zoology, Lahore, Pakistan \\ eUniversity of Sialkot, Department of Biotechnology, Sialkot, Pakistan \\ fUniversity of Gujrat, Department of Zoology, Gujrat, Pakistan
}

\begin{abstract}
Pheretima posthuma (Vaillant, 1868), a native earthworm of Pakistan and Southeast Asia, has wide utilization in vermicomposting and bioremediation process. In this study, P. posthuma coelomic fluid (PCF) and body paste (PBP) was evaluated as antibacterial agent against ampicillin (AMP) resistant five Gram positive and four Gram negative clinical isolates. The antibacterial effect of different doses (i.e. $25-100 \mu \mathrm{g} / \mathrm{ml}$ ) of PCF and PBP along with AMP and azithromycin (AZM) (negative and positive controls, respectively) were observed through disc diffusion and microdilution methods. All nine clinical isolates were noticed as AMP resistant and AZM sensitive. Antibacterial effects of PCF and PBP were dose dependent and zone of inhibitions (ZI) against all clinical isolates were between $23.4 \pm$ 0.92 to $0 \pm 00 \mathrm{~mm}$. The sensitivity profile of PCF and PBP against clinical isolates was noticed as 44.44 and $55.56 \%$, respectively. Both PCF and PBP showed bacteriostatic (BTS) action against S. aureus, S. pyogenes, K. pneumonia, N. gonorrhoeae. Moreover, the cumulative BTS potential of PCF and PBP against all isolates was 66.67 and 55.56\%, respectively. The MICs of PCF and PBP were ranged from $50-200 \mu \mathrm{g} / \mathrm{ml}$ against selected isolates. The bacterial growth curves indicated that PCF and PBP inhibited the growth of all isolates at their specific MIC concentrations. However, PBP has better antibacterial potential compared to PCF against selected isolates. Therefore, it is concluded that both PCF and PBP of P. posthuma possess antibacterial and BTS potential against ampicillin resistant clinical isolates. This organism might be considered as a second choice of antibacterial agents and can further be utilized in pharmaceutical industries for novel drug manufacturing by prospecting bioactive potential agents.
\end{abstract}

Keywords: earthworm paste, minimum inhibitory concentration, bacterial growth curves, resistant bacteria.

\section{Resumo}

Pheretima posthuma (Vaillant, 1868), uma minhoca nativa do Paquistão e sudeste da Ásia, tem ampla utilização em processos de vermicompostagem e biorremediação. Neste estudo, o fluido celômico de $P$. posthuma (PCF) e a pasta corporal (PBP) foram avaliados como agente antibacteriano contra cinco isolados clínicos Gram-positivos e quatro Gram-negativos resistentes à ampicilina (AMP). O efeito antibacteriano de diferentes doses (ou seja, 25-100 $\mu \mathrm{g} /$ $\mathrm{ml}$ ) de PCF e PBP juntamente com AMP e azitromicina (AZM) (controles negativo e positivo, respectivamente) foi observado por meio de métodos de difusão em disco e microdiluição. Todos os nove isolados clínicos foram notados como resistentes a AMP e sensíveis a AZM. Os efeitos antibacterianos de PCF e PBP foram dependentes da dose e a zona de inibição (ZI) contra todos os isolados clínicos foi entre $23,4 \pm 0,92$ a $0 \pm 00 \mathrm{~mm}$. O perfil de sensibilidade do PCF e PBP contra isolados clínicos foi observado como $44,44 \%$ e 55,56\%, respectivamente. Tanto o PCF quanto o PBP mostraram ação bacteriostática (BTS) contra S. aureus, S. pyogenes, K. pneumonia, N. gonorrhoeae. Além disso, o potencial BTS cumulativo de PCF e PBP contra todos os isolados foi de 66,67\% e 55,56\%, respectivamente. Os

*e-mail: iramliaq@hotmail.com

Received: December 27, 2020 - Accepted: February 20, 2021 
MICs de PCF e PBP variaram de 50-200 $\mu \mathrm{g}$ / ml contra isolados selecionados. As curvas de crescimento bacteriano indicaram que o PCF e o PBP inibiram o crescimento de todos os isolados em suas concentrações específicas de MIC. No entanto, PBP tem melhor potencial antibacteriano em comparação com PCF contra isolados selecionados. Portanto, conclui-se que tanto o PCF quanto o PBP de P. posthuma possuem potencial antibacteriano e BTS contra isolados clínicos resistentes à ampicilina. Esse organismo pode ser considerado como uma segunda escolha de agentes antibacterianos e pode ainda ser utilizado nas indústrias farmacêuticas para a fabricação de novos medicamentos por meio da prospecção de agentes com potencial bioativo.

Palavras-chave: pasta de minhoca, concentração inibitória mínima, curvas de crescimento bacteriano, bactérias resistentes.

\section{Introduction}

Earthworms are reddish to dark brown, tubular, segmented and macro-invertebrate oligochaete worms found in soil. They are so called "farmer's friend", because these worms enhance the fertility and productivity of soil during burrowing activity (Bhorgin and Uma, 2014). The soil fertility gets increased due to air and water penetration through burrows (Katsvairo et al., 2007) and addition of high concentration of organic and inorganic compounds in the form of nitrogenous waste in the soil through worm casting (Krishnamoorthy and Vajranabhaiah, 1986). The natural processes of earthworms are frequently used to reduce pollutants (i.e. heavy metals) by bioremediation (Wang et al., 2018; Selvi et al., 2019) and to degrade toxic compounds through gut enzymes and microbial agents (Rudi et al., 2009; Byzov et al., 2015; Liu et al., 2018). They are also used as big source of protein and widely used in poultry and fish industry as source of food (Sogbesan et al. 2007; Parolini et al. 2020).

Earthworms have also been utilized in medicines for treatment against various diseases since $1340 \mathrm{AD}$ (Cooper, 2009; Omar et al., 2012). Earthworm's tissue extracts, coelomic fluid and body paste possess various agents (i.e. proteins) that have been well documented as antiulcer (Prakash et al., 2007), anti-coagulant (Popoviæ et al., 2001), antiviral (Liu et al., 2012), antibacterial (Aydoğdu and Çotuk, 2008; Balamurugan et al., 2010; Chauhan et al., 2014), antifungal (Vasanthi et al., 2013), antitumor (Cooper et al., 2004; Chen et al., 2007; Hua et al., 2011; Augustine et al., 2018), anti-inflammatory (Balamurugan et al., 2007; Mathur et al., 2011), cytotoxic (Rudrammaji et al., 2008; Endharti et al., 2019), antipyretic and analgesic agents (Prakash and Gunasekaran, 2011).

Among variety of earthworms, Pheretima sp. of these worms was reported in eastern India, South East Asia and Japan as an endemic population (Darmawan et al., 2012). In Pakistan, P. posthuma was found abundant among other species of earthworms in different habitats like green chili, wheat, bitter gourd, sorghum, pumpkin, jantar, millet and rice (Sarwar et al., 2006; Ghafoor et al., 2008). Owing to relative abundance of $P$. posthuma in Pakistan, current study utilized it as experimental organism and assessed the antibacterial and bacteriostatic potential of coelomic fluid as well as body paste against both Gram positive (Bacillus cereus, Staphylococcus aureus, Streptococcus pyogenes, Pseudomonas aeruginosa and Bacillus pumilus) and Gram negative (Klebsiella pneumonia, Pseudomonas putida, Neisseria gonorrhoeae and Escherichia coli) bacteria isolated from clinical settings.

\section{Materials and Methods}

\subsection{Sample collection}

Earthworms were collected by digging up soil at $35 \mathrm{~cm}$ depth with scraper (Ansari and Sitaram, 2011) from bank sides of Marala Ravi Link (MRL) canal near village kanwalit (32²0'54.5”N 74²5'34.1"E) Sialkot region, July to September 2019. Moist, shady, grassy and pesticide free land sites were selected for sampling which were confirmed by earthworm's casting (Ramnarain et al., 2016). Mature earthworms were, then, hand sorted on the basis of presence and absence of clitellum (Singh et al., 2016). For identification, these worms were transported in soil to Microbiology Laboratory, Department of Zoology, GC University Lahore. Earthworms were morphologically identified on the basis of skin color, clitellum shape, number of segments and prostomium under binocular microscope by using the figures and keys designed by Blakemore (2012).

\subsection{P. posthuma Coelomic Fluid (PCF) collection}

In order to prepare $P$. posthuma coelomic fluid (PCF), earthworms were rinsed and cleaned with sterile water to remove dirt from the body surface. They were allowed to clear their guts for 48 hours on moist filter paper in wide and deep plastic tray, covered with polythene paper having pin holes. After gut clearing, they were again washed with water and placed on dry filter paper to absorb excess water from body surface. 20 g earthworms were weighed and placed in a cone shaped funnel that was fit on iron stand. A clean sterile nylon mesh was used and placed in this funnel to prevent the escape of worm. For heat shock, $15 \mathrm{ml}$ warm water $\left(45-50^{\circ} \mathrm{C}\right)$ in a thick plastic bag was utilized for 3-5 minutes. This warm water stimulated the body surface of worm to secrete (PCF) from dorsal pores (Patil and Biradar, 2017). After ten minutes, which minimize the warm shock effect, earthworms were given cold shock treatment. In this method, a pack of ice cube was put over same worms to give cold shock. The ice cube lowered the temperature of earthworm body surface from $10-15^{\circ} \mathrm{C}$ that agitated the worm to discharge PCF which was collected in $10 \mathrm{ml}$ dry beaker. The collected PCF was then transferred to sterilized test tubes. PCF was centrifuged at 4500-5000 rpm for 12 minutes to remove debris and impurities. Supernatant was filtered through $0.2 \mu \mathrm{m}$ syringe filter and filtered PCF was stored in sterile eppendorf at $-20^{\circ} \mathrm{C}$ (Esaivani et al., 2017). 


\subsection{Formation of P. posthuma Body Paste (PBP)}

The earthworms ( $P$. posthuma) were cleaned with tap water and placed on moist blotting paper to remove undigested matter from gut for $24 \mathrm{~h}$. To minimize the impurities, the worms were again washed with sterile water. The earthworms were placed in plastic container which was firmly covered with polythene sheet. After covering, container was exposed to sunlight to kill worms for 3 days. During this period, released coelomic fluid and mucous digested the dead body of worms and formed P. posthuma body paste (PBP) having brown colour. The PBP was filtered and the filtrates acquired were condensed at $35^{\circ} \mathrm{C}$ using water-bath. The crude PBP gained was diluted with $10 \%$ DMSO for evaluation of antibacterial activity (Vasanthi et al., 2013).

\subsection{Bacterial strains}

For antibacterial assay, 5 Gram positive and 4 Gram negative human pathogenic bacterial isolates were obtained from bacterial collection center of Microbiology Laboratory, Department of Zoology, GC University Lahore, Pakistan. The list of these bacterial isolates is given in Table 1 .

\subsection{Ampicillin Sensitivity Test (AST)}

Ampicillin sensitivity test was performed using ampicillin disc (10 $\mu \mathrm{g} /$ disc) following Kirby-Bauer disc agar diffusion method (Younis et al., 2020). Inhibition zones were noted after overnight incubation of pathogenic bacteria against ampicillin discs. The resistant bacterial isolates were selected for further study.

\subsection{Antibacterial assay}

For antibacterial assay, disc diffusion method was designed with slight modification of Bhorgin and Uma (2014) to find the inhibitory zones and order of antibiotic sensitivity of clinical isolates. Findings were interpreted, according to Clinical and Laboratory Standards Institute (CLSI) guideline, as resistant (R), intermediate (I) and sensitive $(S)$. For this purpose, fresh bacterial cultures were prepared by inoculating a full loop of bacteria from the selected pathogenic stock strains into flasks of muller hinton broth (MHB) and kept in incubator at $37^{\circ} \mathrm{C}$ overnight. Following incubation, concentrated fresh bacterial cultures were diluted into $\mathrm{MHB}$ to attain $10^{6} \mathrm{CFU} / \mathrm{ml}$. $15 \mathrm{ml}$ of muller hinton $(\mathrm{MH})$ agar was poured into sterile petriplates and allowed to solidify for 10 minutes. $150 \mu$ l of diluted bacterial culture was spread and five sterile filter paper discs of $6 \mathrm{~mm}$ diameter were placed on agar media surface. On these sterile discs, the various concentrations (25, 50,75 and $100 \mu \mathrm{g} / \mathrm{disc}$ ) of PCF or PBP were loaded with sterile micropipette and allowed to diffuse for 10 minutes. Plates were incubated at $37^{\circ} \mathrm{C}$ for 24 hours. Inhibition zones (ZI) of diameter ( $\mathrm{mm}$ ) were measured and recorded with standard zone reader scale. A disc of Azithromycin (AZM $15 \mu \mathrm{g} /$ disc) was used in each bacterial assay as positive control while resistant Ampicillin (10 $\mathrm{g}$ /disc) was used as negative control. All assays were performed in triplicates. These assays utilized the earlier study of Shoeib and Alkufeidy (2014) to interpret the clinically isolated bacterial sensitivity to various tested PCF or PBP concentrations using vancomycin antibiotic as standard to Gram +ve and Imipenem antibiotic to Gram -ve bacteria.

\subsection{Minimum Inhibitory Concentration (MIC)}

MIC was assessed following slight modification of broth micro-dilution method using stock solution of fresh bacterial cultures (Lazzarotto-Figueiró et al., 2019). Ten serial two-fold dilutions of PCF and PBP were formed to get final dilution range (i.e. $400-0.781 \mu \mathrm{g} / \mathrm{ml}$ ). $150 \mu \mathrm{L}$ of fresh bacterial MH broth were taken in 96 well micro-test plates with sterile tips of micropipette. For each clinical isolate, 3 columns of ten sterile wells of 96 -well were utilized. So that, each well consist of $150 \mu \mathrm{L}$ of broth culture supplemented with PCF or PBP concentrations and $50 \mu \mathrm{L}$ of clinical isolate inoculum. The 96-well micro-test plates were wrapped with aluminum foil and placed in incubator at $37^{\circ} \mathrm{C}$ for 24 hours. The inhibition of clinical isolates was checked by visual inspection of turbidity in test wells compared to control. The PCF or PBP concentrations at which no visible growth appeared were declared as MICs. Subsequently, the $50 \mu \mathrm{L}$ was also spread on nutrient agar

Table 1. Pathogenic bacterial isolates (i.e. Gram +ve and Gram -ve) and their sources.

\begin{tabular}{|c|c|c|c|c|}
\hline Sr. No. & Clinical isolates & Genbank accession No. & Source samples & Studied by \\
\hline \multicolumn{5}{|c|}{ Gram +ve isolates } \\
\hline 1 & B. cereus & JQ580958.1 & Sputum & Ali et al. (2015) \\
\hline 2 & S. aureus & NC_007793.1 & Leucorrhea Fluid & Ali et al. (2019) \\
\hline 3 & S. pyogenes & СР013840.1 & Air of operation theater & Ali et al. (2019) \\
\hline 4 & P. aeruginosa & СР027538.1 & Air of operation theater & Ali et al. (2019) \\
\hline 5 & B. pumilus & JN037409.1 & Clinical waste water & Jahan et al. (2016) \\
\hline \multicolumn{5}{|c|}{ Gram -ve isolates } \\
\hline 1 & K. pneumonia & NR_037084.1 & Sputum & Ali et al. (2015) \\
\hline 2 & P. putida & EU239209.1 & Sputum & Ali et al. (2015) \\
\hline 3 & N. gonorrhoeae & AE004969 & Leucorrhea Fluid & Ali et al. (2019) \\
\hline 4 & E. coli & NC_000913.2 & Leucorrhea Fluid & Ali et al. (2019) \\
\hline
\end{tabular}


plates to confirm absence of growth. All tests were arranged in triplicate and the mean values of MICs were expressed.

\subsection{Bacteriostatic analysis}

For bacteriostatic analysis, bacterial growth curve was measured following method by Whitaker and Alshammari (2017) with slight modification. Each clinical bacterial isolate was cultured by mixing a $160 \mu \mathrm{l}$ of bacterial suspension (OD = 1.5) to $6 \mathrm{ml}$ of $\mathrm{MH}$ media. Bacterial growth was recorded by measuring turbidity at $600 \mathrm{~nm}$ using a spectrophotometer. Following 3 hours incubation at $37^{\circ} \mathrm{C}$, PCF was mixed at its MIC value. Turbidity was measured by checking $\mathrm{OD}_{600}$ after 6 hours. Bacterial cells were centrifuged to form pellets, washed thrice with sterilized isotonic saline and pellets were poured back into $6 \mathrm{ml}$ sterile $\mathrm{MH}$ media. Following another 15 hours incubation (i.e. total 24 hours), the turbidity was again measured to check the bacterial growth. For control group, bacterial culture was incubated without PCF addition to generate growth curve. Experiments were run $3 \mathrm{X}$ for each clinical bacterial isolate. Same experiment was performed in triplicate for PBP to evaluate its effect against clinical bacteria.

\section{Results}

The antibacterial and bacteriostatic aspects of PCF and PBP extracted from $P$. posthuma were assessed against ampicillin resistant five Gram +ve (B. cereus, S. aureus, S. pyogenes, P. aeruginosa and B. pumilus) and four Gram -ve (K. pneumonia, P. putida, N. gonorrhoeae and E. coli) clinical isolates by ampicillin sensitivity test (AST), antibacterial assay, MIC test and bacteriostatic assay.

\subsection{Antibacterial assay}

The results of antibacterial assay (i.e. disc diffusion method) were summarized in Figures 1,2 . The influence of various concentrations (i.e. 25, 50, 75 and $100 \mu \mathrm{g} /$ disc) of PCF and PBP along with AMP (as -ve control) and AZM (as +ve control) were observed as inhibitory zone $(\mathrm{ZI}=\mathrm{mm}$ ) against all clinical isolates. All the nine clinical isolates were noticed as AMP resistant and AZM sensitive. While, two Gram +ve (i.e. B. cereus and P. aeruginosa) and one Gram -ve (i.e. $N$. gonorrhoeae) were appeared highly resistant against AMP because there was no any ZI against these isolates. Similarly, B. cereus as Gram +ve isolate showed highest sensitivity ( $\mathrm{ZI}=30.1 \pm 1.12$ ) against AZM followed by $S$. aureus $>B$. pumilus $>P$. aeruginosa $>S$. pyogenes while for Gram -ve highest ZI was shown by K. pneumonia $(\mathrm{ZI}=28.1 \pm 1.34)$. Whereas, the antibacterial effect of PCF was found directly proportional to the PCF concentrations used in all tests setting against clinical isolates. The ZIs by all the PCF concentrations ranged between $22.1 \pm 0.92$ to $0 \pm 00$ against all clinical isolates. The antibacterial impact of PCF was studied highest to lowest as follows B. pumilus $>$ B. cereus $>$ S. pyogenes $>$ S. aureus $>$ P. aeruginosa for Gram + ve. Moreover, it was also examined against Gram -ve isolates (but lower than Gram +ve) and sequenced from high to low as N. gonorrhoeae $>$ P. putida $>$ K. pneumonia $>$ E. coli (Figure 1).
Similar to PCF, PBP also showed a dose dependent antibacterial effect. PBP showed growth inhibitory results similar to PCF (100 $\mu \mathrm{g} /$ disc) at $75 \mu \mathrm{g} /$ disc dose. While using PBP $(100 \mu \mathrm{g} /$ disc $)$, the largest inhibitory zone was observed against $B$. cereus (23.4 $\pm 0.94 \mathrm{~mm}$ ) among Gram +ve and N. gonorrhoeae (21.77 $\pm 0.94 \mathrm{~mm})$ among Gram -ve isolates. Results indicated that PBP has higher antibacterial potential than PCF because larger ZI were observed against clinical isolates using PBP. This work clearly demonstrated that coelomic fluid and body pate of $P$. posthuma has antibacterial effect against both Gram +ve and Gram -ve clinical isolates (Figure 2).

The results regarding sensitivity pattern (i.e. sensitive (S), intermediate (I) and resistant (R) and bacteriostatic/bacteriocidal (BTS/BTC) of PCF and PBP along with AMP and AZM for Gram +ve and Gram -ve clinical isolates were summarized in Table 2 . All clinical isolates were highly resistant $(\mathrm{R})$ aganist antibiotic AMP (-ve control) while sensitive (S) aganist AZM (+ve control). The efficiency impact of PCF and PBP on the basis of sensitivity against all isolates was observed as 44.44 and $55.56 \%$ respectively. Among 9 clinical isolates, three Gram +ve (i.e. B. cereus, S. pyogenes, and B. pumilus) and two Gram -ve (P. putida and N. gonorrhoeae) were highly sensitive while only $P$. aeruginosa was resistant against PCF and PBP. The intermediate effect of PCF and PBP was noticed against $K$. pneumonia isolate only while $S$. aureus and E. coli were intemediately effected solely by PBP.

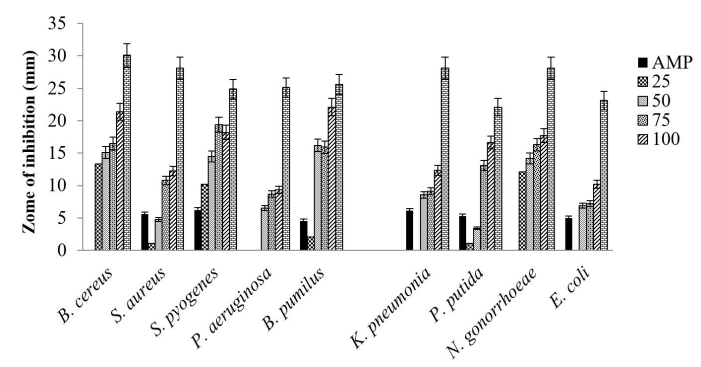

Figure 1. Antibacterial effect of different concentrations $(25-100 \mu \mathrm{g} / \mathrm{ml})$ of P. posthuma coelomic fluid (PCF) against Gram +ve and -ve clinical isolates. Ampicillin (AMP) and azithromycin (AZM) were used as -ve and +ve controls, respectively.

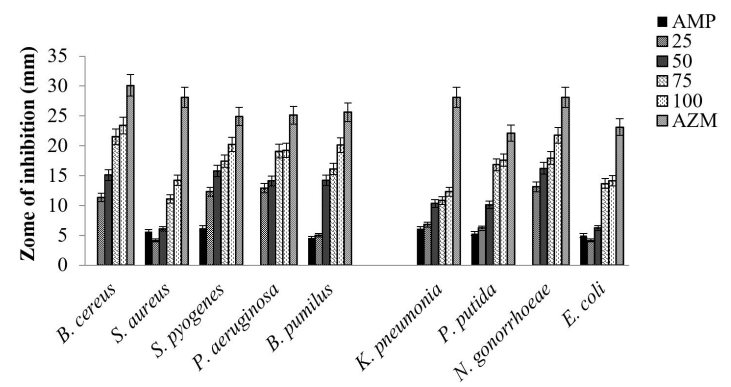

Figure 2. Antibacterial effect of different concentrations

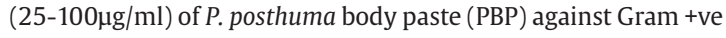
and -ve clinical isolates. Ampicillin (AMP) and azithromycin (AZM) were used as -ve and +ve controls, respectively. 
To check the bacteriostatic (BTS) and bacteriocidal (BTC) effect of PCF and PBP, the isolated bacteria from inhibition zone were re-inoculated on nutreint agar plates. PCF and PBP has BTS (i.e. inhibitory) effect against S. aureus, S. pyogenes, K. pneumonia, N. gonorrhoeae. Similarly, the growth of $P$. aeruginosa and E. coli were inhibited by PCF while PBP revealed same effects against B. pumilus. Moreover, the total BTS effects of PCF and PBP were 66.67 and $55.56 \%$ against all isolates. In the same manner, the results regarding BTC (bacteiocidal) effect of PCF and PBP were 33.33 and 44.44\% against both Gram +ve and Gram -ve isolates.

\subsection{Minimum inhibitory concentrations of PCF and PBP}

For bacterial growth curve, results about MICs of PCF and PBP against different bacterial isolates were presented in Table 3. The MICs of PCF and PBP for nine different

Table 2. Bacteriostatic (BTS) and bacteriocidal (BTC) potential of P. posthuma coelomic fluid (PCF) and P. posthuma body paste (PBP) against clinical isolates.

\begin{tabular}{|c|c|c|c|c|c|c|c|c|}
\hline \multirow[b]{2}{*}{ Clinical isolate } & \multicolumn{2}{|c|}{ AMP $(10 \mu \mathrm{g} /$ disk $)$} & \multicolumn{2}{|c|}{ PCF $(100 \mu \mathrm{g} /$ disk $)$} & \multicolumn{2}{|c|}{ PBP $(100 \mu g /$ disk $)$} & \multicolumn{2}{|c|}{ AZM $(30 \mu \mathrm{g} /$ disk $)$} \\
\hline & IZ (mm) & $\begin{array}{c}\text { BTS/BTC } \\
\text { effect }\end{array}$ & $\mathrm{IZ}(\mathbf{m m})$ & $\begin{array}{c}\text { BTS/BTC } \\
\text { effect }\end{array}$ & IZ (mm) & $\begin{array}{c}\text { BTS/BTC } \\
\text { effect }\end{array}$ & IZ (mm) & $\begin{array}{c}\text { BTS/BTC } \\
\text { effect }\end{array}$ \\
\hline \multicolumn{9}{|l|}{ Gram +ve isolate } \\
\hline B. cereus & $0^{R}$ & ND & $21^{\mathrm{s}}$ & BTC & $23^{s}$ & BTC & $30^{\mathrm{s}}$ & BTC \\
\hline S. aureus & $6^{R}$ & BTC & $12^{\mathrm{R}}$ & BTS & $14^{\mathrm{I}}$ & BTS & $28^{s}$ & BTS \\
\hline S. pyogenes & $6^{\mathrm{R}}$ & BTS & $18^{\mathrm{s}}$ & BTS & $20^{\mathrm{s}}$ & BTS & $25^{\mathrm{s}}$ & BTC \\
\hline P. aeruginosa & $0^{R}$ & ND & $9^{R}$ & BTS & $11^{\mathrm{R}}$ & BTC & $25^{s}$ & BTS \\
\hline B. pumilus & $5^{\mathrm{R}}$ & BTC & $22^{\mathrm{s}}$ & BTC & $20^{s}$ & BTS & $26^{\mathrm{s}}$ & BTC \\
\hline \multicolumn{9}{|l|}{ Gram-ve isolate } \\
\hline K. pneumonia & $6^{R}$ & BTS & $12^{1}$ & BTS & $12^{1}$ & BTS & $28^{\mathrm{s}}$ & BTC \\
\hline P. putida & $5^{\mathrm{R}}$ & BTS & $17^{\mathrm{s}}$ & BTC & $18^{\mathrm{s}}$ & BTC & $22^{\mathrm{s}}$ & BTS \\
\hline N. gonorrhoeae & $0^{R}$ & ND & $18^{\mathrm{s}}$ & BTS & $22^{\mathrm{s}}$ & BTS & $28^{\mathrm{s}}$ & BTC \\
\hline E. coli & $5^{\mathrm{R}}$ & BTC & $10^{\mathrm{R}}$ & BTS & $14^{\mathrm{I}}$ & BTC & $23^{s}$ & BTC \\
\hline \% Efficiency & 0 & - & 44.44 & - & 55.56 & - & 100 & - \\
\hline \% BTS & - & 50 & - & 66.67 & - & 55.56 & - & 33.33 \\
\hline$\%$ BTC & - & 50 & - & 33.33 & - & 44.44 & - & 66.67 \\
\hline
\end{tabular}

According to CLSI (2001), Vancomycin (VA) containing $10 \mu \mathrm{g} /$ disk was used as standard for Gram +ve isolates where, Resistant (R) $\leq 10 \mathrm{~mm}$, intermediate (I) $\geq 11-14 \mathrm{~mm}$ and Sensitive (S) $\geq 15 \mathrm{~mm}$. For Gram -ve, imipenem (IPM) containing $10 \mu \mathrm{g} / \mathrm{disk}$ was used as standard for G -ve isolates where, Resistant $(R) \leq 13 \mathrm{~mm}$, Intermediate $(\mathrm{I}) \geq 14-15 \mathrm{~mm}$ and Sensitive $(\mathrm{S}) \geq 16 \mathrm{~mm}$. BTS (Bacteriostatic), BTC (Bacteriocidal), AMP (Ampicillin), AZM (Azithromycin)

Table 3. Minimum inhibitory concentrations of $P$. posthuma coelomic fluid (PCF) and $P$. posthuma body paste (PBP) against clinical isolates.

\begin{tabular}{|c|c|c|c|c|c|c|c|c|c|c|c|c|c|c|c|c|c|c|}
\hline \multirow{3}{*}{$\begin{array}{l}\text { Concentration } \\
(\mu \mathrm{g} / \mathrm{ml})\end{array}$} & \multicolumn{10}{|c|}{ Gram +ve isolates } & \multicolumn{8}{|c|}{ Gram -ve isolates } \\
\hline & \multicolumn{2}{|c|}{ B. cereus } & \multicolumn{2}{|c|}{ S. aureus } & \multicolumn{2}{|c|}{ S. pyogenes } & \multicolumn{2}{|c|}{$\begin{array}{c}P . \\
\text { aeruginosa }\end{array}$} & \multicolumn{2}{|c|}{ B. pumilus } & \multicolumn{2}{|c|}{$\begin{array}{c}\text { K. } \\
\text { pneumonia }\end{array}$} & \multicolumn{2}{|c|}{ P. putida } & \multicolumn{2}{|c|}{$\begin{array}{c}N . \\
\text { gonorrhoeae }\end{array}$} & \multicolumn{2}{|c|}{ E. coli } \\
\hline & PCF & PBP & PCF & PBP & PCF & PBP & PCF & PBP & PCF & PBP & PCF & PBP & PCF & PBP & PCF & PBP & PCF & PBP \\
\hline 400 & - & - & - & - & - & - & - & - & - & - & - & - & - & - & - & - & - & - \\
\hline 200 & - & - & - & - & - & - & - & - & - & - & - & - & - & - & - & - & - & - \\
\hline 100 & - & - & + & - & - & - & - & - & - & - & - & - & - & - & - & - & - & - \\
\hline 50 & + & - & + & - & + & + & - & + & + & - & + & - & - & + & + & - & - & - \\
\hline 25 & + & + & + & + & + & + & + & + & + & + & + & + & + & + & + & + & + & + \\
\hline 12.5 & + & + & + & + & + & + & + & + & + & + & + & + & + & + & + & + & + & + \\
\hline 6.25 & + & + & + & + & + & + & + & + & + & + & + & + & + & + & + & + & + & + \\
\hline 3.13 & + & + & + & + & + & + & + & + & + & + & + & + & + & + & + & + & + & + \\
\hline 1.56 & + & + & + & + & + & + & + & + & + & + & + & + & + & + & + & + & + & + \\
\hline 0.781 & + & + & + & + & + & + & + & + & + & + & + & + & + & + & + & + & + & + \\
\hline MIC & 100 & 50 & 200 & 50 & 100 & 100 & 50 & 100 & 100 & 50 & 100 & 50 & 50 & 100 & 100 & 50 & 50 & 50 \\
\hline
\end{tabular}

$+\operatorname{sign}$ (growth of bacteria), - sign (no growth of bacteria) 
clinical isolates ranged from 50 to $200 \mu \mathrm{g} / \mathrm{ml}$. Whereas, $200 \mu \mathrm{g} / \mathrm{ml}$ dose of PCF inhibited the growth of $S$. aureus while at $100 \mu \mathrm{g} / \mathrm{ml}$ concentration, the growth of B. cereus, S. pyogenes, B. pumilus, K. pneumonia and N. gonorrhoeae was inhibited. In case, to find the lowest inhibitory concentration of PBP as antibacterial agent, $100 \mu \mathrm{g} / \mathrm{ml}$ dose was suitable to inhibit the growth of two Gram +ve (i.e. S. pyogenes and $P$. aeruginosa) and one Gram -ve (P. putida) isolate. Likewise, $50 \mu \mathrm{g} / \mathrm{ml}$ concentration was sufficient to inhibit the growth of 6 clinical isolates from which three were Gram +ve isolates (B. cereus, S. aureus, B. pumilus) and two Gram -ve bacteria (K. pneumonia, N. gonorrhoeae and E. coli). These MICs concentration were further utilized to find its effect on bacterial growth curve.

\subsection{Bacteriostatic action and growth curve determination}

MIC concentrations were further utilized to detect their effect on growth inhibition of bacterial isolates. The growth curves were assessed for bacterial strains that were already analyzed for BTS action. After 3 hrs incubation at log phase, all selected sensitive clinical isolates were separately exposed to PCF and PBP for period of 3 to 10 hours. Bacteriostatic growth curves of PCF (Figure 3 ) were derived against each of seven PCF sensitive isolates such as S. aureus, P. aeruginosa, S. pyogenes, K. pneumonia, $N$. gonorrhoeae, E. coli and B. pumilus. The results indicated that five isolates (i.e. S. aureus, S. pyogenes, P. aeruginosa, $K$. pneumonia, N. gonorrhoeae) showed excellent ZI in growth

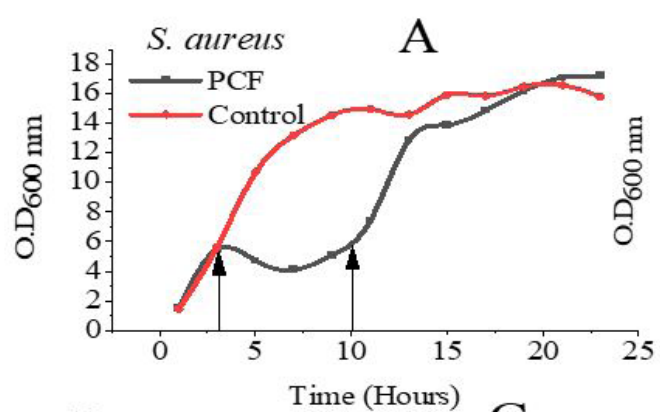

P. aenuginosa

B
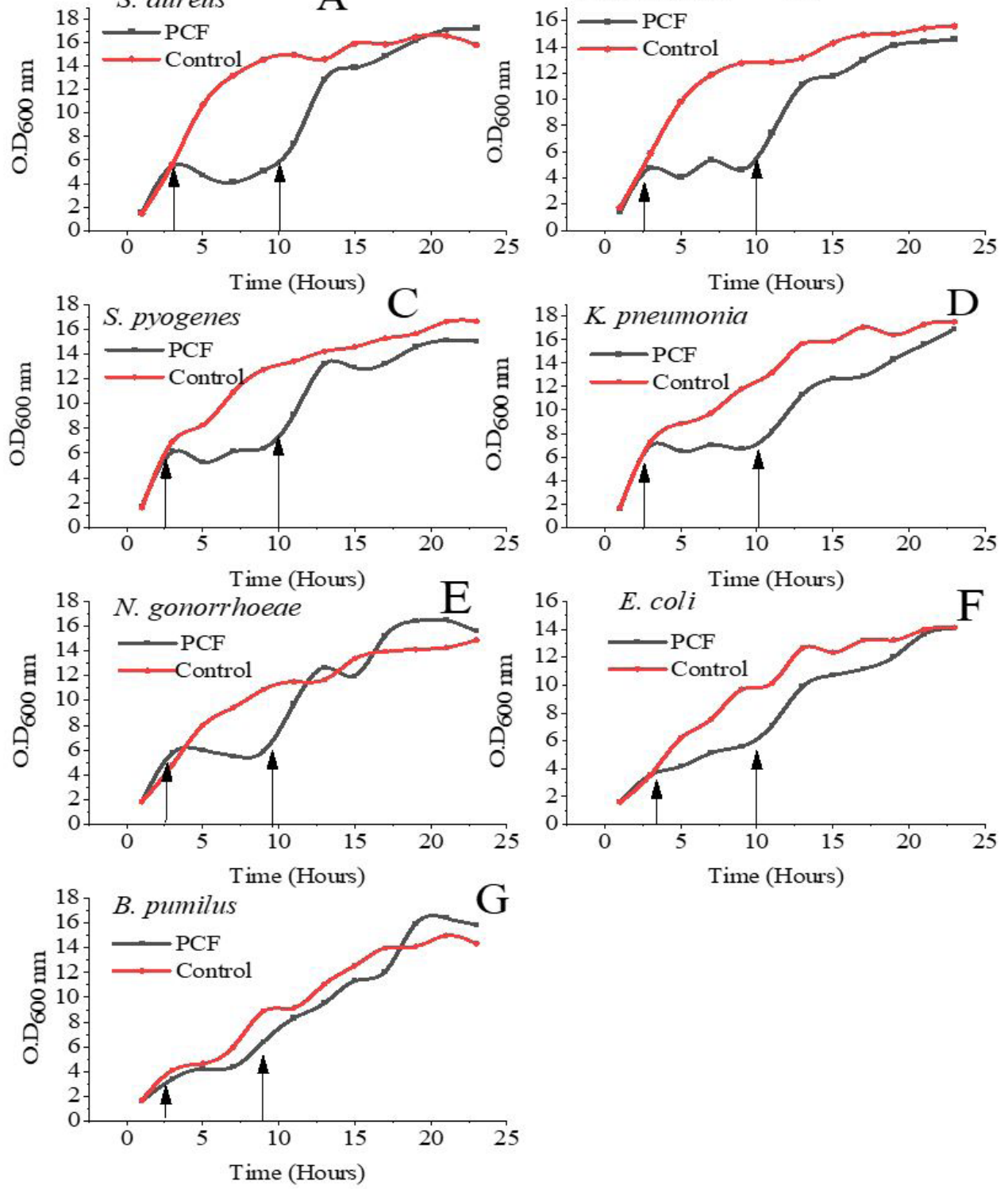

S. pyogenes (C), K. pneumonia (D), N. gonorroeae (E), E. coli (F) B. pumilus (G) Control. 
curves compared to E. coli and B. pumilus. Similarly, these curves were also derived against five PBP sensitive bacterial isolates (S. pyogenes, K. pneumonia, P. aeruginosa, S. aureus and $B$. putida) as shown in Figure 4. The findings of growth curve determined that both PCF and PBP inhibit/ slows down the growth of particular Gram +ve and Gram -ve clinical isolates compared to control which lack PCF and PBP concentration. However, removal of clinical isolates from broth media containing PCF and PBP MIC concentrations, these bacterial isolates again started to multiply indicating that bacterial growth were inhibited due to presence of PCF and PBP.

\section{Discussion}

The antibacterial agents are ubiquitous molecules because they are found in eminent environment as well as in plants, vertebrates, invertebrates and also in microorganisms. However, there is a need to find more efficient, appropriate and natural alternatives to combat increasing bacterial resistance against available antibiotics with emphasis on specificity against particular pathogens. The present study explored the earthworm's coelomic fluid and body paste potential against clinical bacterial pathogens (both Gram +ve and Gram -ve) owing to the fact that earthworms live in microbially contaminated environment, which stimulates the production of antimicrobial agents in their body as defensive molecules (Liu et al., 2012). These molecules (i.e. proteins or lipids) naturally respond in an organism as defensive agents against broad diversity of clinical isolates, thus play effective role to evoke innate immunity (Prakash and Gunasekaran, 2011).

As first step, this study screened all nine clinical pathogens by using disc diffusion assay and found all isolates as ampicillin resistant. This resistance was due to $\beta$-lactamase enzyme synthesis (Ash et al., 2002) and in rare cases $\beta$-lactamase negative ampicillin resistance was also reported in clinically isolated bacteria (Barry et al., 2001). Likewise, ampicillin resistance against Gram
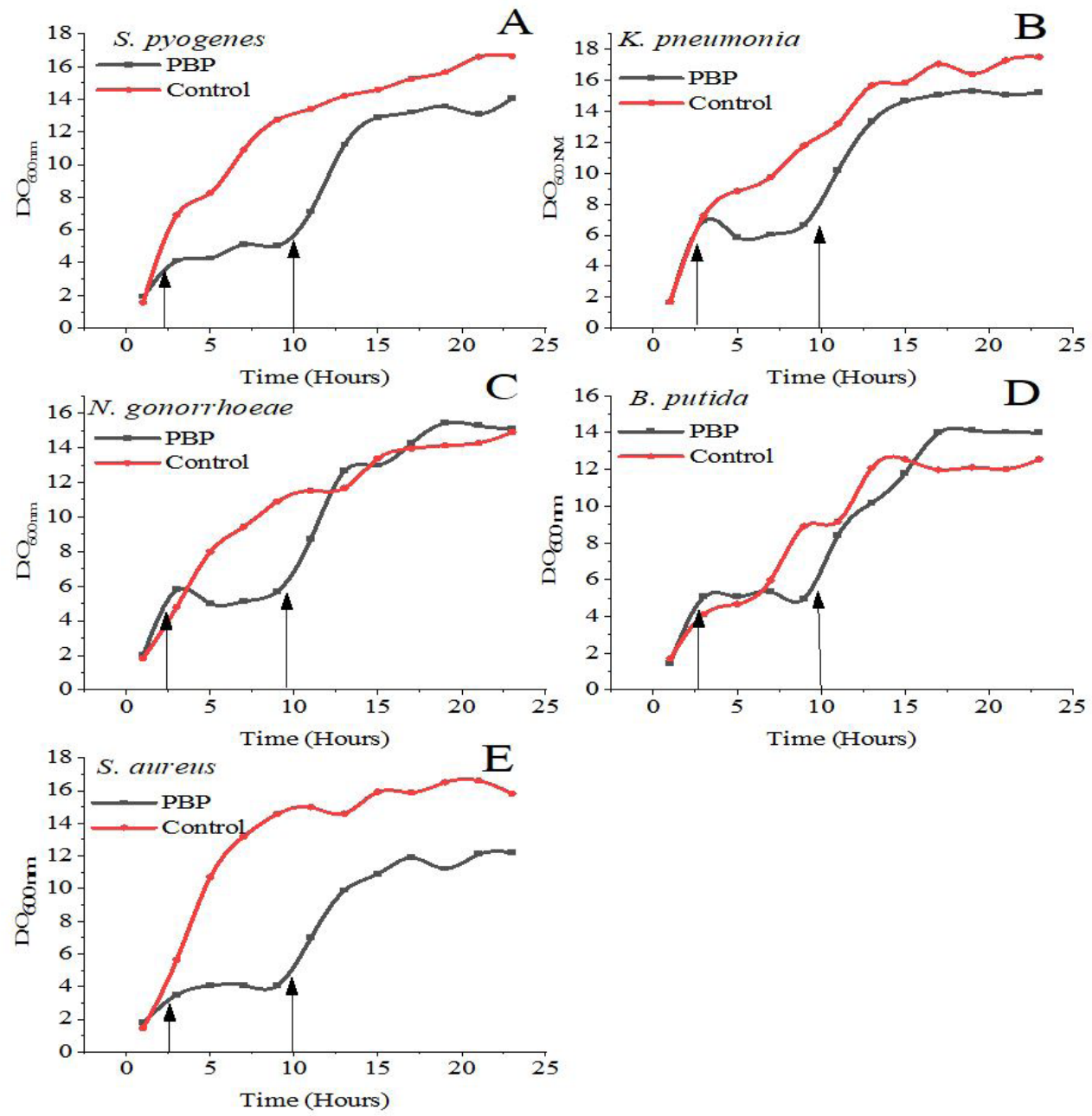

Figure 4. Arrows indicate bacteriostatic zone of PBP against sensitive clinical isolates S. pyogenes (S), K. pneumonia (B), N. gonorroeae (C) B. putida (D) S. aureus (E) Control. 
+ve and -ve pathogenic isolates was well reported by other researchers (Kulkarni et al., 2019 and Breijyeh et al., 2020).

The results from this research also revealed that the ZI against all selected Gram +ve and -ve clinically isolated bacteria during all PCF and PBP experimental setups were dose dependent (highest at $100 \mu \mathrm{g} / \mathrm{disc}$ ) and ranged between $23.4 \pm 1.42$ to $0 \pm 00 \mathrm{~mm}$. Where, zone of inhibition is a microbe free area around the antimicrobial agent on the agar plates (Dharmawati et al., 2019). This microbe free area guaranteed the present of antimicrobial agent (Barnard, 2019). Result regarding, variations in ZI was due to varying amounts of antibacterial agent in PCF and PBP concentrations (25, 50, 75 and $100 \mu \mathrm{g} /$ disc) utilized in this examination. These findings corroborate with the results by Prakash and Gunasekaran (2011) and Chauhan et al. (2014).

Our next step was to determine the antibacterial potential of PCF and PBP, it was observed that three Gram positive (B. cereus, S. pyogenes and B. pumilus) and two Gram negative (P. putida and $N$. gonorrhoeae) showed sensitivity for $\mathrm{PCF}(100 \mu \mathrm{l} / \mathrm{disc})$ while $S$. aureus, $P$. aeruginosa (Gram positive) and E. coli (Gram negative) were found resistant. Similarly, the findings of Vasanthi et al. (2013) and Bansal et al. (2015) support the results of sensitivity but regret the resistant behavior of $S$. aureus, $P$. aeruginosa and E. coli. The current results of $\mathrm{PBP}(100 \mu \mathrm{l} /$ disc $)$ antibacterial potential was much better than PCF because only one bacterial strain ( $P$. aeruginosa) was resistant while all other were appeared either sensitive or intermediate. Ansari and Sitaram (2011) also reported that Eisenia fetida (earthworm) powder possesses strong antibacterial potential against $S$. aureus and $E$. coli. The antibacterial potential was due to presence of number of bioactive compounds (like proteins and peptides) in earthworms that behave as antimicrobial agent (Engelmann et al., 2004; Patil and Biradar, 2017). The lumbricin I (peptide) was the first antimicrobial molecules extract from Lumbricus rubellus which showed antimicrobial potential against a broad range of microorganisms (Cho et al., 1998). Wang et al. (2003) also identified two other antimicrobial agents (OEP3121 and PP1) from E. foetida and P. tschiliensis respectively. Likewise, another antimicrobial peptide called lumbricin-PG was obtained from secretions released from P. guillelmi skin (Li et al., 2011). Our results regarding MICs of PCF and PBP against 9 different bacterial isolates ranged from 50 to $200 \mu \mathrm{g} / \mathrm{ml}$. These findings are consistent with the study by Esaivani et al. (2017).

Final step was to check the effect of PCF and PBP on bacterial growth curves which proved the inhibitory potential of both PCF and PBP. Following removal of isolates from media containing either PCF/PBP, and re-inoculation in fresh broth, they started to grow. This indicated that PCF and PBP has inhibitory effect on the growth of isolates. Similarl findings were reported by Cynthia et al. (2014), who studied the bacteriostatic impact of Lampito mauritii's cell extract and coelomic fluid on pathogens and observed inhibitory nature of $L$. mauritii's extract. This bacteriolytic action might be due to presence of antimicrobial peptides as observed in case of earthworm species, $P$. guillelmi (Li et al., 2011).

\section{Conclusion}

The antibiotic resistance in bacterial strains is increasing day by day due to frequent and misuse of antibiotics in clinical trials. To overcome this problem, there is a dire need to generate or discover new antibacterial agents. This study was an attempt to introduce a new source of antibacterial agents as effective natural alternative to antibiotics. The results of this study suggested that coelomic fluid and body paste of earthworm (P. posthuma) has bacteriostatic and bacteriocidal potential against Gram $+v e$ and -ve clinical bacteria. This indicates the presence of antimicrobial agents (proteins and peptides) in coelomic fluid and body paste. Thus, P. posthuma (earthworm) is a good source of antibacterial agents that are in need to be identified and extracted as source of cheap medicines to control serious infections.

\section{Reference}

ALI, M.N., HUSSAIN, M., MAZHAR, S.A., MZAHAR, B., KALIM, B., REHMAN, S. and SHAHZAD, M., 2015. Molecular characterization and antibiotic resistance of bacterial pathogens from respiratory tract infection. Merit Research Journal of Medicine and Medical Science, vol. 3, no. 8, pp. 325-334.

ALI, N.M., SHAHZAD, M., BANO, M., LIAQAT, I., MAZHAR, B., ZAIN, S. and YAQUB, A., 2019. Antibiogram analysis and characterization of bacterial pathogens from leucorrhea patients. Microbiology Research Journal International, vol. 28, no. 1, pp. 1-13. http:// dx.doi.org/10.9734/mrji/2019/v28i130124.

ANSARI, A.A. and SITARAM, K., 2011. An investigation into the antimicrobial and antifungal properties of earthworm powder obtained Eisenia fetida. American Journal of Food Technology, vol. 6, no. 4, pp. 329-335. http://dx.doi.org/10.3923/ajft.2011.329.335.

ASH, R.J., MAUCK, B. and MORGAN, M.M., 2002. Antibiotic resistance of Gram-negative bacteria in rivers, United States. Emerging Infectious Diseases, vol. 8, no. 7, pp. 713-716. http://dx.doi. org/10.3201/eid0807.010264. PMid:12095440.

AUGUSTINE, D., RAO, R.S., ANBU, J. and MURTHY, K.N.C, 2018. Anticancer prospects of earthworm extracts: a systematic review of in vitro and in vivo studies. Pharmacognosy Reviews, vol. 12, no. 23, pp.46-55. http://dx.doi.org/10.4103/phrev.phrev_45_17.

AYDOĞDU, E.A. and ÇOTUK, A., 2008. Antibacterial and hemolytic activity of the coelomic fluid of Dendrobaena veneta (Oligochaeta, Lumbricidae) living in different localities. European Journal of Biology, vol. 67, no. 1, pp. 23-32.

BALAMURUGAN, M., PARTHASARATHI, K., COOPER, E.L. and RANGANATHAN, L.S., 2007. Earthworm paste (Lampito mauritii, Kinberg) alters inflammatory, oxidative, haematological and serum biochemical indices of inflamed rat. European Review for Medical and Pharmacological Sciences, vol. 11, no. 2, pp. 77-90. PMid:17552137.

BALAMURUGAN, V., VENKATESAN, G., SEN, A., ANNAMALAI, L., BHANUPRAKASH, V. and SINGH, R.K., 2010. Recombinant protein based viral disease diagnostics in veterinary medicine. Expert Review of Molecular Diagnostics, vol. 10, no. 6, pp. 731-753. http://dx.doi.org/10.1586/erm.10.61. PMid:20843198.

BANSAL, N., GUPTA, R.K., SINGH, D. and SHASHANK, A., 2015. Comparative study of antibacterial activity of two different earthworm species, Perionyx excavatus and Pheretima posthuma against pathogenic bacteria. Journal of Applied and Natural 
Science, vol. 7, no. 2, pp. 666-671. http://dx.doi.org/10.31018/ jans.v7i2.664.

BARNARD, R.T., 2019. The zone of inhibition. Clinical Chemistry, vol. 65, no. 6, pp. 819. http://dx.doi.org/10.1373/clinchem.2018.299800. PMid:31138553.

BARRY, A.L., FUCHS, P.C. and BROWN, S.D., 2001. Identification of beta lactamase negative, ampicillin resistant strains of Haemophilus influenzae with four methods and eight media. Antimicrobial Agents and Chemotherapy, vol. 45, no. 5, pp. 1585-1588. http:// dx.doi.org/10.1128/AAC.45.5.1585-1588.2001. PMid:11302835.

BHORGIN, A.J. and UMA, K., 2014. Antimicrobial activity of Earthworm Powder (Lampito mauritii). International Journal of Current Microbiology and Applied Sciences, vol. 3, no. 1, pp. 437-443.

BLAKEMORE, R. J., 2012. On Schmarda's lost worm and some newly found New Zealand species. Journal of Species Research, vol. 1, no. 2, pp. 105-132.

BREIJYEH, Z., JUBEH, B. and KARAMAN, R., 2020. Resistance of Gram negative bacteria to current antibacterial agents and approaches to resolve it. Molecules, vol. 25, no. 6, pp. 1340-1345. http://dx.doi.org/10.3390/molecules25061340. PMid:32187986.

BYZOV, B.A., TIKHONOV, V.V., NECHITAILO, T.Y., DEMIN, V.V. and ZVYAGINTSEV, D.G., 2015. Taxonomic composition and physiological and biochemical properties of bacteria in the digestive tracts of earthworms. Eurasian Soil Science, vol. 48, no. 3, pp. 268-275. http://dx.doi.org/10.1134/S1064229315030035.

CHAUHAN, P.S., TOMAR, J., PRASAD, G.B.K.S. and AGRAWAL, O.P., 2014. Evaluation of antimicrobial activity of earthworm Eudrilus eugeniae tissue extract. Journal of Chemical and Pharmaceutical Research, vol. 6, no. 8, pp. 28-38.

CHEN, H., TAKAHASHI, S., IMAMURA, M., OKUTANI, E., ZHANG, Z., CHAYAMA, K. and CHEN, B., 2007. Earthworm fibrinolytic enzyme: anti-tumor activity on human hematoma cells in vitro and in vivo. Chinese Medical Journal, vol. 120, no. 10, pp. 898-904. http://dx.doi.org/10.1097/00029330-20070502000009. PMid:17543180.

CHO, J.H., PARK, C.B., YOON, Y.G. and KIM S.C., 1998. Lumbricin I, a novel proline-rich antimicrobial peptide from the earthworm: purification, cDNA cloning and molecular characterization. Biochimica et Biophysica Acta (BBA)-Molecular basis of disease, vol. 1408, no. 1, pp. 67-76.

CLINICAL \& LABORATORY STANDARDS INSTITUTE - CLSI, 2001. Development of in vitro susceptibility testing criteria and quality control parameters Approved guideline CLSI/NCCLS Document M23-A2. 2nd ed. Wayne: CLSI/NCCLS.

COOPER, E., HRZENJAK, T.M. and GRDISA, M., 2004. Alternative source of fibrinolytic, anticoagulative, antimicrobial and anticancer molecules. International Journal of Immunopathology and Pharmacology, vol. 17, no. 3, pp. 237-244. http://dx.doi. org/10.1177/039463200401700303. PMid:15461857.

COOPER, E.L., 2009. A closer look at clinical analyses. Evidence-Based Complementary and Alternative Medicine, vol. 6, no. 3, pp. 279281. http://dx.doi.org/10.1093/ecam/nep099. PMid:19656800.

CYNTHIA, J.M., UMA, K. and DEVI, U.R., 2014. Bacteriostatic effect of Lampito mauritii (Kinberg) coelomic fluid and cell extract on pathogens. International Journal of Current Microbiology and Applied Sciences, vol. 3, no. 3, pp. 182-186.

DARMAWAN, A., RAFFIUDIN, R. and WIDARTO, T.H., 2012. Morphological characters and histology of Pheretima darnleiensis. Hayati Journal of Biosciences, vol. 19, no. 1, pp. 44-48. http:// dx.doi.org/10.4308/hjb.19.1.44.

DHARMAWATI, I.G.A.A., MAHADEWA, T.G.B. and WIDYADHARMA, A.A., 2019. Antibacterial activity of Lumbricus Rubellus earthworm extract Against Porphyromonas Gingivalis as the bacterial cause of periodontitis. Open Access Macedonian Journal of Medical Sciences, vol. 7, no. 6, pp. 1032-1036. http://dx.doi. org/10.3889/oamjms.2019.222. PMid:30976356.

ENDHARTI, A.T., PURNAMASARI, Y., PRIMASARI, R., POERANTO, S. and PERMANA, S., 2019. Coelomic fluid of Lumbricus rubellus synergistically enhances cytotoxic effect of 5-Fluorouracil through modulation of focal adhesion kinase and P21 in HT-29 cancer cell line. The Scientific World Journal, vol. 2019, pp. 5632859. http://dx.doi.org/10.1155/2019/5632859. PMid:31097925.

ENGELMANN, P., KISS, J., CSÖNGEI, V., COOPER, E.L. and NÉMETH, P., 2004. Earthworm leukocytes kill HeLa, HEp-2, PC-12 and PA317 cells In Vitro. Journal of Biochemical and Biophysical Methods, vol.61, no. 1-2, pp. 215-227. http://dx.doi.org/10.1016/j. jbbm.2004.04.004. PMid:15560938.

ESAIVANI, C., VASANTHI, K. and SINGH, A.J.A.R., 2017. An investigation on antimicrobial potency of coelomic fluid of earthworm Eudrilus eugeniae. British Journal of Medical and Health Research, vol. 4, no. 4, pp. 1-7.

GHAFOOR, A., HASSAN, M. and ALVI, Z.H., 2008. Biodiversity of earthworm species from various habitats of district Narowal, Pakistan. International Journal of Agriculture and Biology, vol. 10, pp. 681-684.

HUA, Z., WANG, Y.H., CAO, H.W., PU, L.J. and CUI, Y.D., 2011. Purification of a protein from coelomic fluid of the earthworm Eisenia foetida and evaluation of its haemolytic, antibacterial, and antitumor activities. Pharmaceutical Biology, vol. 49, no. 3, pp. 269-275. http://dx.doi.org/10.3109/13880209.2010.50 8498. PMid:21323479.

JAHAN, N., IDREES, M., ZAHID, M., ALI, N.M. and HUSSAIN, M., 2016. Molecular identification and characterization of heavy metal resistant bacteria and their role in bioremediation of chromium. Microbiology Research Journal International, vol. 13, no. 6, pp. 1-11.

KATSVAIRO, T.W., WRIGHT, D.L., MAROIS, J.J., HARTZOG, D.L., BALKCOM, K.B., WIATRAK, P.P. and RICH, J.R., 2007. Cotton roots, earthworms, and infiltration characteristics in sodpeanut-cotton cropping systems. Agronomy Journal, vol. 99, no. 2, pp. 390-398. http://dx.doi.org/10.2134/agronj2005.0330.

KRISHNAMOORTHY, R.V. and VAJRANABHAIAH, S.N., 1986. Biological activity of earthworm casts: an assessment of plant growth promoter levels in the casts. Procceedings: Animal Science, vol. 95, pp. 341-351.

KULKARNI, A.P., NAGVEKAR, V.C., VEERARAGHAVAN, B., WARRIER, A.R., TS, D., AHDAL, J. and JAIN, R., 2019. Current perspectives on treatment of gram-positive infections in India: what is the way forward? Interdisciplinary Perspectives on Infectious Diseases, vol. 2019, p. 7601847. http://dx.doi.org/10.1155/2019/7601847. PMid:31080476.

LAZZAROTTO-FIGUEIRÓ, J., CAPELEZZO, A.P., SCHINDLER, M.S.Z., FOSSÁ, J.F.C., ALBENY-SIMÕES, D., ZANATTA, L., OLIVEIRA, J.V. and DAL MAGRO, J., 2021. Antioxidant activity, antibacterial and inhibitory effect of intestinal disaccharidases of extracts obtained from Eugenia uniflora L. Seeds. Brazilian Journal of Biology = Revista Brasileira de Biologia, vol. 81, no. 2, pp. 291-300. http://dx.doi.org/10.1590/1519-6984.224852. PMid:32696852.

LI, W., LI, S., ZHONG, J., ZHU, Z., LIU, J. and WANG, W., 2011. A novel antimicrobial peptide from skin secretions of the earthworm, Pheretima guillelmi (Michaelsen). Peptides, vol. 32, no. 6, pp. 1146-1150. http://dx.doi.org/10.1016/j.peptides.2011.04.015. PMid:21539875. 
LIU, D., LIAN, B., WU, C. and GUO, P., 2018. A comparative study of gut microbiota profiles of earthworms fed in three different substrates. Symbiosis, vol. 74, pp. 21-29. http://dx.doi. org/10.1007/s13199-017-0491-6.

LIU, Z., WANG, J., ZHANG, J., YU, B. and NIU, B., 2012. An extract from the earthworm Eisenia fetida non-specifically inhibits the activity of influenza and adenoviruses. Journal of Traditional Chinese Medicine, vol. 32, no. 4, pp. 657-663. http://dx.doi. org/10.1016/S0254-6272(13)60088-6. PMid:23427406.

MATHUR, A., VERMA, S.K., SINGH, S.K., PRAKASH, A., PRASAD, G.B.K.S. and DUA, V.K., 2011. Anti-inflammatory activity of earthworm extracts. International Journal of Pharmaceutical Sciences and Research, vol. 2, no. 2, pp. 278-281.

OMAR, H.E.D.M., IBRAHEIM, Z.Z., ELSHIMY, N.A. and ALI, R.S., 2012. Anti-inflammatory, antipyretic and antioxidant activities of the earthworms extract. Journal of Biology and Earth Sciences, vol. 2, pp. 1-6.

PAROLINI, M., GANZAROLI, A. and BACENETTI, J., 2020. Earthworm as an alternative protein source in poultry and fish farming: current applications and future perspectives. The Science of the Total Environment, vol. 734, pp. 139460. http://dx.doi. org/10.1016/j.scitotenv.2020.139460. PMid:32454339.

PATIL, S.R. and BIRADAR, P.M., 2017. Earthworm's coelomic fluid: extraction and importance. International Journal of Advanced Scientific Research, vol. 2, no. 2, pp. 1-4.

POPOVIÆ, M., ENJAK, T.M.H.R., BABIÆ, T., KOS, J. and MIRA, G.A., 2001. Effect of earthworm (G-90) extract on formation and lysis of clots originated from venous blood of dogs with cardiopathies and with malignant tumors. Pathology Oncology Research, vol. 7, no. 3, pp. 197-202. http://dx.doi.org/10.1007/BF03032349. PMid:11692146.

PRAKASH, M. and GUNASEKARAN, G., 2011. Antibacterial activity of the indigenous Earthworms Lampito mauritii (Kinberg) and Perionyx excavatus (Perrier). Journal of Alternative and Complementary Medicine (New York, N.Y.), vol. 17, no. 2, pp. 167 170. http://dx.doi.org/10.1089/acm.2009.0720. PMid:21299431.

PRAKASH, M., BALAMURUGAN, M., PARTHASARATHI, K., GUNASEKARAN, G., COOPER, E.L. and RANGANATHAN, L.S., 2007. Anti-ulceral and anti-oxidative properties of "earthworm paste" of Lampito mauritii (Kinberg) on Rattus Norvegicus. European Review for Medical and Pharmacological Sciences, vol. 11, no. 1, pp. 9-15. PMid:17405344.

RAMNARAIN, Y.I., ANSARI, A.A. and ORI, L., 2016. Research report on one local earthworm species in suriname. Journal of Biology and Nature, vol. 5, no. 1, pp. 26-30.

RUDI, K., ODEGARD, K., LOKKEN, T.T. and WILSON, R., 2009. A feeding induced switch from a variable to a homogenous state of the earthworm gut microbiota within a host population. PLoS One, vol. 4, no. 10, pp. e7528. http://dx.doi.org/10.1371/ journal.pone.0007528. PMid:19841743.
RUDRAMMAJI, L.M.S., SUMASRIDHAR, M.S., DINESH, A. and SONOLE, V.G., 2008. Cytotoxic effect of coelomic fluid of earthworm Eudrilus eugeniae. Biomedical \& Pharmacology Journal, vol. 1, no. 2, pp. 433-436.

SARWAR, M., NADEEM, A., IQBAL, M.K. and SHAFIQ, T., 2006. Biodiversity of earthworm species relative to different flora. Punjab University Journal of Zoology, vol. 21, no. 1-2, pp. 1-7.

SELVI, A., RAJASEKAR, A., THEERTHAGIRI, J., ANANTHASELVAM, A., SATHISHKUMAR, K., MADHAVAN, J. and PKSM, R., 2019. Integrated remediation processes toward heavy metal removal/ recovery from various environments-A Review. Frontiers of Environmental Science E' Engineering, vol. 7, no. 66, pp. 1-15.

SHOEIB, A.A. and ALKUFEIDY, R.M.S., 2014. Bacteriostatic or bactericidal action of four aqueous plant extracts on multidrug resistant bacteremia and their effect on cells morphology recorded using scanning electron microscopy (SEM). African Journal of Microbiological Research, vol. 8, no. 44, pp. 3732-3742.

SINGH, S., SINGH, J. and VIG, A.P., 2016. Effect of abiotic factors on the distribution of earthworms in different land use patterns. Journal of Basic \& Applied Zoology, vol. 74, pp. 41-50. http:// dx.doi.org/10.1016/j.jobaz.2016.06.001.

SOGBESAN, O.A., UGWUMBA, A.A.A., MADU, C.T., EZE, S.S. and ISA, J., 2007. Culture and utilization of earthworm as animal protein supplement in the diet of Heterobranchus longifilis fingerlings. Journal of fisheries and Aquatic Science, vol. 2, no. 6, pp. 375-386.

VASANTHI, K., CHAIRMAN, K. and SINGH, A.J.A.R., 2013. Antimicrobi nal activity of earthworm (Eudrilus eugeniae) paste. African Journal of Environmental Science and Technology, vol. 7, no. 8, pp. 789-793. http://dx.doi.org/10.5897/AJEST2013.1455.

WANG, K., QIAO, Y., ZHANG, H., YUE, S., LI, H., JI, X. and LIU, L., 2018. Bioaccumulation of heavy metals in earthworms from field contaminated soil in a subtropical area of China. Ecotoxicology and Environmental Safety, vol. 148, pp. 876-883. http://dx.doi. org/10.1016/j.ecoenv.2017.11.058.

WANG, X., WANG, X.X., ZHANG, Y., QU, X. and YANG, S., 2003. An antimicrobial peptide of the earthworm Pheretima tschiliensis: cDNA cloning, expression and immunolocalization. Biotechnology Letters, vol. 25, no. 16, pp. 1317-1323. http://dx.doi. org/10.1023/A:1024999206117. PMid:14514059.

WHITAKER, E.J. and ALSHAMMARI, A., 2017. Bacteriostatic effect of simvastatin on selected oral streptococci In Vitro. Contemporary Clinical Dentistry, vol. 8, no. 1, pp. 59-63. http://dx.doi. org/10.4103/ccd.ccd_848_16. PMid:28566853.

YOUNIS, G.A., ELKENANY, R.M. and DOWIDAR, H.A., 2020. Virulence genotyping and antimicrobial resistance profiles of Yersinia enterocolitica isolated from meat and meat products in Egypt. Brazilian Journal of Biology = Revista Brasileira de Biologia, vol. 81 , no. 2, pp. $424-436$ 